\title{
The Effect of Planting Time and Density of Corn (Zea Mays L.) On The Growth and Yield of Taro (Colocasia Esculenta L.)
}

\author{
Schott var. Antiquorum in Intercropping \\ Retno Tri Purnamasari ${ }^{1)}$, Dawam Maghfoer ${ }^{2)}$, Nur Edy Suminarti ${ }^{2)}$ \\ 1) Master Program of Plant Science, Faculty of Agriculture, University of Brawijaya, \\ Jl. Veteran, Malang, 65145, East Java, Indonesia; \\ ${ }^{2)}$ Faculty of Agriculture, University of Brawijaya, Jl. Veteran, Malang, 65145, East Java, Indonesia;
}

\begin{abstract}
Objectives of the research were (1) to study the effect of planting time and density of corns on the growth and the yield of taro, which is grown in intercropping system, and (2) to determine the right planting time and appropriate density of corn in order to obtain optimal growth and yield of taro in intercropping system. Research in the field was conducted at Landungsari Village, Malang from September 2012 to July 2013. The research used a Split Plots Design by placing the planting time of corn as the main plot, which comprised of 3 levels, such as : (1) the corn was grown 30 days earlier before the taro, (2) the corn and the taro were grown simultaneously, and (3) the corn was grown 30 days later after planting the taro. The plant density was placed as the son plot, which includes 3 types: (1) 15,000 plants ha ${ }^{-1}$, (2) 29,000 plants hal, and (3) 43,000 plants ha-1. The treatments have been done by 3 replications.

Results of the research showed that the appropriate time of planting corn in intercrop system with taro was growing both crops simultaneously, and they have produced taro tubers for about 13.51 tons ha $a^{-1}$ or 30 days after planting, the yield of taro tubers were 14.12 tons $\mathrm{ha}^{-1}$, so that they produced higher yield of taro. Meanwhile, for the corn density of 15,000 plants ha ${ }^{-1}$ have produced the highest yield of taro, 16.13 tons ha-1.
\end{abstract}

Keywords: Planting time, Density level, Corn (Zea mays L.) and Taro (Colocasia esculenta (L.) Schott var. Antiquorum

\section{Introduction}

The rapid growth of population has been followed by the increasing demand of foods, particularly rice. However, the demand has not been able to be fulfilled immediately due to the decreasing productivity of rice in Indonesia. This is due to the decreasing land area for farming, particularly wet land (rice-field) that has changed into non-farming land, such as for settlements, stores, and etc (Suwarto, 2005). In relation to the problem above, and in order to make the land use and varying plants to be efficient, intercrop is presumed as the most appropriate strategy.

Intercrop is one of planting system that combining two or more plants in the same farming land at the same or different time (Mimbar, 1994). Considerations that concern with the selection of plant types for intercrop according to Gliessman (2006) include (1) the plants with different rooting depths; (2) the plants with different photosynthetic lines; and (3) the plants with different requirements of nutrients.

Besides those requirements, the success in planting the intercrop has also been affected by the planting time arrangement and the intercrops density (Finlay, 1974). Planting time arrangement is an alternative to increase productivity of the farm land, because planting time will affect the achievable production. Therefore, planting time arrangement should be concerned in order to obtain better yield (Syaifuddin, 2008). Results of the research (Ridwan et al., 1995) stated that the planting of peanuts between two rows of corn in $100 \mathrm{~cm}$ spacing, has been able to produce 2.93 ton ha ${ }^{-1}$ dry legumes.

Reasons why taro is selected as the intercrop include (1) taro is potential as carbohydrate sources, which is healthy and safe to be consumed. It is due to this crop contains low starch (amylum) and reduction sugar in comparison with sweet potato, cassava, bentol tuber, mbothe tuber, as well as ground rice (Suminarti, 2009). (2) Taro tuber is an essential exported-commodity nowadays. But, in accordance with the yield per land area unit and time, the yield is low, $5-7$ ton ha ${ }^{-1}$, particularly in the farmer level, while the potential production has reached 20.7 ton ha ${ }^{-1}$ (Onwueme, 1978 and Suminarti, 2009). Such lower yield is presumed as a result of : (1) in general, taro is planted in the yard as a mixed cropping by irregular layout, (2) varied spacing of the crops due to no guidance of the standard spacing. In connection with the problem, this research is required in order to gain information and solution, as well as to facilitate the taro management to increase its productivity.

Objectives of the research were (1) to study the effect of planting time arrangement and density of corns on the growth and the yield of taro, which is grown in intercropping system, and (2) to determine the right 
planting time and appropriate density of corn in order to obtain optimal growth and yield of taro in intercropping system.

\section{Material And Method}

The research applied a Split Plots Design (SPD) by 3 replications. The planting time of corn was placed as the main plot (J), which comprised of 3 levels, such as : (1) the corn was grown 30 days earlier before the taro $\left(\mathrm{J}_{1}\right),(2)$ the corn and the taro were grown simultaneously $\left(\mathrm{J}_{2}\right)$, and $(3)$ the corn was grown 30 days later after planting the taro $\left(\mathrm{J}_{3}\right)$. The plant density was placed as the son plot $(\mathrm{P})$, which includes 3 levels: (1) 15,000 plants ha ${ }^{-1}\left(\mathrm{P}_{1}\right)$, (2) 29,000 plants ha ${ }^{-1}\left(\mathrm{P}_{2}\right)$, and (3) 43,000 plants ha ${ }^{-1}\left(\mathrm{P}_{3}\right)$. Based on both treatments, 9 combinations of treatments and along with 3 replications, 27 units of treatment combinations have been obtained.

Instruments of the research include: analytic scales, leaf area meter, oven, sliding calipers, thermometer, and lux meter. Materials of the research include taro germs var. Antiquorum, corn seeds of Pioneer P-21 variety, $\mathrm{K}\left(\mathrm{KCl}: 60 \% \mathrm{~K}_{2} \mathrm{O}\right)$ fertilizer, $\mathrm{N}$ (Urea : 45\% N) fertilizer, and phosphate (SP-36 : $36 \%$ $\mathrm{P}_{2} \mathrm{O}_{5}$ ) fertilizer, as well as goat manure as compost (300 gram plant ${ }^{-1}$ ).

Parameter of observation on the taro plant : The observation was conducted destructively by taking 2 plants as sample for each combination, which was done at 70, 107, 140 dap and at the harvest time (at 175 dap) that included growth and yield components.

Growth and yield components of the taro plant include : numbers of leaf, numbers of plantlet, total dry weight and the tuber yield (ton $\mathrm{ha}^{-1}$ ).

The obtained data will be analyzed using analysis of variance (F-test) at the level $p=0.05$, and if any significant effect existed, it would be followed by SSD test at the level of $p=0.05$.

\section{Result And Discussion}

Results of the research showed a significant interaction between planting time and density of corns on the observed variable of taro that include number of leaf (Table 1), number of plantlet (Table 3), dry weight of total plant (Table 4), and yield of tuber (ton ha ${ }^{-1}$ ) (Table 5).

Table 4 shows that the lowest total dry weight of taro was obtained when the corn was planted 30 days earlier before planting the taro, which was combined in diverse density. Meanwhile, total dry weight of the plants reflected the amount of assimilate produced by the plant, which played as energy of the growth.

The growth can be defined as the increasing size, weight, and multiplication of protoplasm (Sitompul and Guritno, 1995). The increasing size and weight of plant are due to the process of cellular extension, cellular prolongation, and cell division, which require some energy. Whereas the energy resulted by the taro plant with the corn, which was planted 30 days before planting the taro, was low, so that the plant's ability to establish new organs was very slow as shown through the result of observation on numbers of leaf, leaf area, and number of plantlet (Table 1, 2, and 3). The comparable report was given by Syaifuddin (2010) that when the corn and mungbean were grown simultaneously, the growth of mungbean did not show any unstressed character. However, when the corn was planted 30 days earlier than the mungbean, it inhibited the growth of mungbean and at last, it produced lower total dry weight of the plants, weight of 100 seeds and the obtainable yields (ton $\mathrm{ha}^{-1}$ ), in which each of them has reduced for about $36.23 \%, 21.84 \%$, and $20.64 \%$, respectively, in comparison with when both crops were planted simultaneously. It has been conformed to other report (Nulhakim et al., 2008), which suggested to plant the sweet corn and peanuts simultaneously or 15 days after the planting of peanuts, therefore, both of them will grow well and produce high yields.

Leaf is the place where the photosynthetic process occurs, and it means that more leaves will extend the area of photosynthetic process of the plant. Meanwhile, leaf area is the capacity of plant to perform the photosynthetic process. Therefore, the plant that has less number of leaf and narrower leaf area will produce less assimilates as well. Assimilate is a simple carbohydrate, which is comprised of three molecular binds, such as $\mathrm{C}$, $\mathrm{H}$, and $\mathrm{O}$, as well as along with other molecules, such as $\mathrm{N}, \mathrm{S}, \mathrm{P}, \mathrm{K}$, and some micronutrients, such as $\mathrm{Mg}$, will construct a carbohydrate. Some of energy from this carbohydrate will be utilized for the plant growth, and the other will be stored as the food reserve and the remains will be stored in the sink.

Such low yield of tuber (ton $\mathrm{ha}^{-1}$ ) has been caused by low components of growth as a result of strict competition between the corn and the taro in obtaining better grown environment factor. Sitompul and Guritno (1995) suggested that competition occurs if an individual of a given plant group exists in a group of other plant, while the grown environment factor is restricted. Such restricted grown environment, both on the soil surface and below the soil surface, will affect the growth and development of the plant, particularly if both two grown environment factors are required in the same time and amount. Competition between crops and weeds toward water, light, and $\mathrm{CO}_{2}$, as well as nutrients, and land, may intra-specific (between individuals in a population) and inter-specific (between two or more populations, for instance between the plants and weeds) (Bomford, 2004). Competition for light and carbon dioxide is highly determined by the canopy structure and the area of 
The Effect of Planting Time and Density of Corn (Zea Mays L.) On The Growth and Yield of ....

photosynthesis; meanwhile, competition for water and nutrients is highly determined by the root activities, pattern of their distributions, and the ability in absorbing water and nutrients. Competition that occurs during the initial growth of vegetative phase is not so affected, but the competition becomes stricter along with the growing plant (Ara,2007).

As a whole, intercropping between corn and taro has still provided some benefits in comparison with monoculture system. Higher values were shown by the calculation result of LER. When the individual plant was observed separately in the intercropping system, it showed that taro and corn has produced lower yield than the taro or corn was planted in monoculture system. As we know that land equivalent ratio (LER) is the sum between the yield of intercrops and the yield of monoculture in the same management level (Paulus,2005).

Table 1. Average numbers of leaf as a result of interaction between different planting time of taro and density of corns at observational time of 105 dap

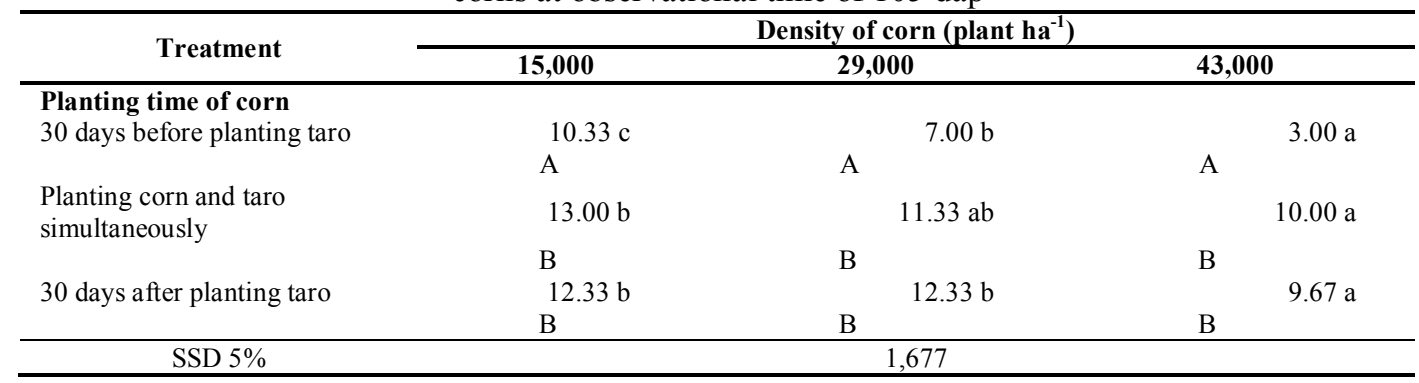

Notes: Numbers followed by the same letter in the same column (capital letter) or in the same row (small letter) at each the age of observation show insignificant difference based on SSD test at the level of 5\%; dap : days after planting

Table 2. Average leaf areas of taro at the whole observational time due to different planting time of taro and density of corns

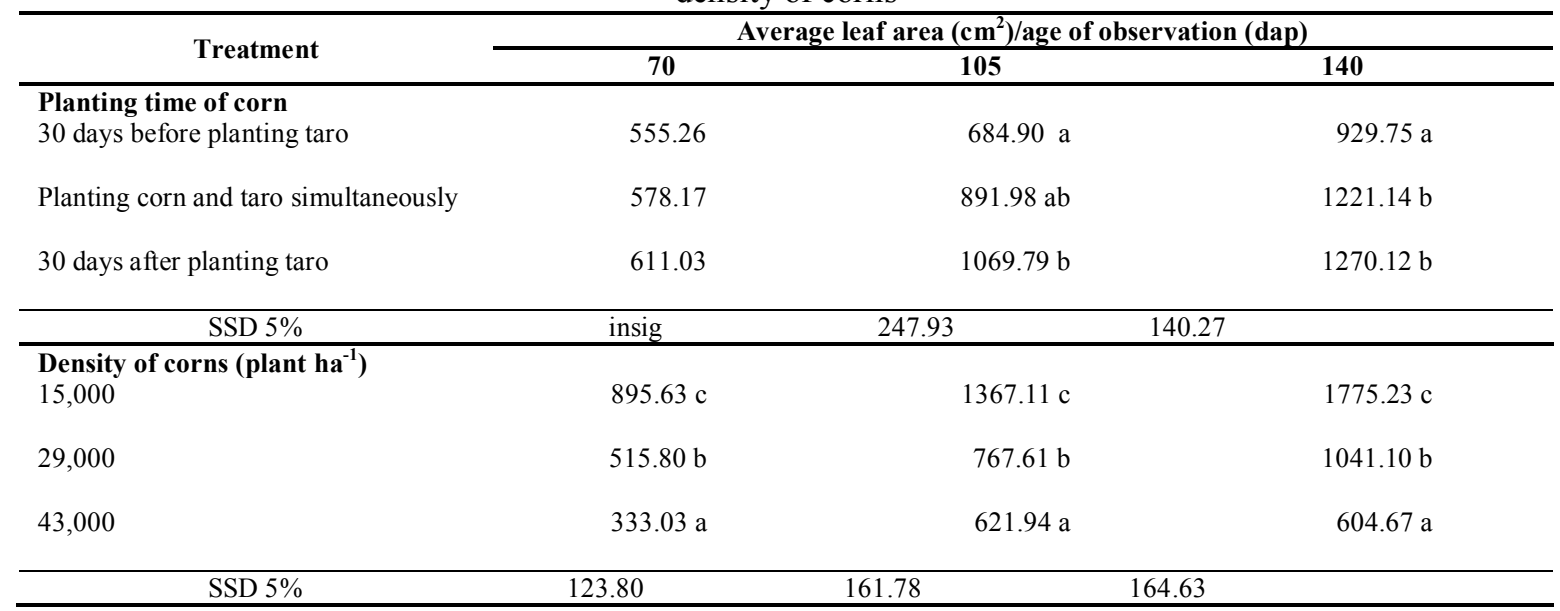

Notes: Numbers followed by the same letter at the same observation age, show insignificant difference based on SSD test at the level $\mathrm{p}=5 \%$. dap $=$ days after planting, insig $=$ insignificant

Table 3. Average numbers of plantlet per plant as a result of interaction between different planting time of taro and density of corns at the age of observation 105 dap

\begin{tabular}{|c|c|c|c|}
\hline \multirow{2}{*}{ Treatment } & \multicolumn{3}{|c|}{ Density of corn (plant $\mathrm{ha}^{-1}$ ) } \\
\hline & 15,000 & 29,000 & 43,000 \\
\hline \multicolumn{4}{|l|}{ Planting time of corn } \\
\hline 30 days before planting taro & A & A & A \\
\hline $\begin{array}{l}\text { Planting corn and taro } \\
\text { simultaneously }\end{array}$ & $9.67 \mathrm{c}$ & $7.00 \mathrm{~b}$ & $3.00 \mathrm{a}$ \\
\hline 30 days after planting taro & $\mathrm{B}$ & $\mathrm{B}$ & $\mathrm{B}$ \\
\hline BNT 5\% & & 1,027 & \\
\hline
\end{tabular}

Notes: Numbers followed by the same letter in the same column (capital letter) or in the same row (small letter) at each the age of observation show insignificant difference based on SSD test at the level of 5\%; dap : days after planting 
The Effect of Planting Time and Density of Corn (Zea Mays L.) On The Growth and Yield of ....

Table 4. Average dry weight of total taro $(\mathrm{g})$ as a result of interaction between different planting time of taro and density of corn at the observation age of 105 dap and 140 dap

\begin{tabular}{|c|c|c|c|}
\hline \multirow{2}{*}{ Treatment } & \multicolumn{3}{|c|}{ Density of corn (plant $\left.\mathrm{ha}^{-1}\right)$} \\
\hline & 15,000 & 29,000 & 43,000 \\
\hline \multicolumn{4}{|l|}{ Planting time of corn } \\
\hline \multirow{2}{*}{30 days before planting taro } & $94.55 \mathrm{~b}$ & $62.15 \mathrm{a}$ & $48.30 \mathrm{a}$ \\
\hline & A & A & A \\
\hline \multirow[t]{2}{*}{ Planting corn and taro simultaneously } & $166.83 \mathrm{c}$ & $91.25 \mathrm{~b}$ & $52.15 \mathrm{a}$ \\
\hline & $\mathrm{B}$ & $\mathrm{B}$ & A \\
\hline \multirow[t]{2}{*}{30 days after planting taro } & $169.86 \mathrm{c}$ & $104.00 \mathrm{~b}$ & $59.92 \mathrm{a}$ \\
\hline & $\mathrm{B}$ & $\mathrm{B}$ & A \\
\hline SSD 5\% & & 26.097 & \\
\hline \multicolumn{4}{|l|}{ Planting time of corn } \\
\hline \multirow[t]{2}{*}{30 days before planting taro } & $139.39 \mathrm{~b}$ & $136.57 \mathrm{~b}$ & $102.34 \mathrm{a}$ \\
\hline & $\mathrm{A}$ & A & A \\
\hline \multirow[t]{2}{*}{ Planting corn and taro simultaneously } & $182.54 \mathrm{c}$ & $142.48 \mathrm{~b}$ & $111.27 \mathrm{a}$ \\
\hline & $\mathrm{B}$ & A & A \\
\hline \multirow[t]{2}{*}{30 days after planting taro } & $211.52 \mathrm{c}$ & $158.49 \mathrm{~b}$ & $111.77 \mathrm{a}$ \\
\hline & $\mathrm{C}$ & $\mathrm{B}$ & A \\
\hline SSD 5\% & & 14.203 & \\
\hline
\end{tabular}

Notes: Numbers followed by the same letter in the same column (capital letter) or in the same row (small letter) at each the age of observation show insignificant difference based on SSD test at the level of 5\%; dap : days after planting

Table 5. Average yields of ton ha ${ }^{-1}$ taro at the harvest time due to different planting time and density of corns

\begin{tabular}{|c|c|c|}
\hline Treatment & \multicolumn{2}{|c|}{ Yield of tuber (ton ha ${ }^{-1}$ ) } \\
\hline \multicolumn{3}{|l|}{ Planting time of corn } \\
\hline 30 days before planting taro & 12.28 & $\mathrm{a}$ \\
\hline Planting corn and taro simultaneously & 13.51 & $\mathrm{~b}$ \\
\hline 30 days after planting taro & 14.12 & $\mathrm{c}$ \\
\hline SSD 5\% & 1.19 & \\
\hline \multicolumn{3}{|l|}{ Density of corn (plant ha $\left.{ }^{-1}\right)$} \\
\hline 15,000 & 16.13 & $\mathrm{c}$ \\
\hline 29,000 & 13.28 & $\mathrm{~b}$ \\
\hline 43,000 & 10.49 & $\mathrm{a}$ \\
\hline
\end{tabular}

Notes: Numbers followed by the same letter show insignificant difference based on SSD test at the level of 5\%

Low yield of taro per individual in intercropping system was caused by less population grown in such planting system. Based on t-test, it can be seen that the highest yield of tubers was derived from the taro plant, which was grown 30 days after planting the corn at the density of 15,000 plants $^{-1}{ }^{-1}, 971.17$ gram plant $^{-1}$. The value was much lower $19.43 \%$ by monoculture than the taro plant itself.

\section{Conclusion}

The appropriate time of planting corn in intercrop system with taro is planting both of the crops simultaneously, and it will produce taro tubers for about 13.51 ton $^{-1} \mathrm{~h}^{-1}$ as well as 30 days after planting the taro, which produces higher yield, 14.12 ton $\mathrm{ha}^{-1}$. The density of corn, 15,000 plants ha ${ }^{-1}$ has also produced the highest yield of taro, 16.13 ton ha ${ }^{-1}$.

\section{Suggestion}

It is recommended to the farmers that higher yield of taro tubers can be obtained by planting the corn 30 days after planting taro plants in the density of 15,000 plant ha $^{-1}$.

\section{References}

[1]. Ara, W, M.K. Bashar, S Beghum and S.S. Kakon. 2007. Effect of Spacing and Stem Pruning and Growth and Yield of Tomato. Int. J. Sustain. Crop Prod. 2(3) : 35-39

[2]. Bomford, K. 2004. Yield, Pest Density, and Tomato Flavor Effects of Companion Planting in Garden-Scale Studies Incorporating Tomato, Basil and Brussels Sprout. Davis College of Agriculture, Forestry and Consumer Sciences at West Virginia University

[3]. Finlay, R.C. 1974. Intercropping Soybeans With Cereals. Regional Soybeans Conference. p. 14-17

[4]. Gliessmen,S.R. 2006. Agroecology Ecological Processes in Sustainable Agriculture. Lewis Publishers. p.213-224

[5]. Hakim, N., M. Y. Nyakpa, A. M. Lubis, S. G. Nugroho, M. A. Diha, G. B. Hong and H. H. Bailey. 1986. The Basics of Soil Science. Publisher for University of Lampung. Lampung.

[6]. Mimbar,1994. The Effect of Intercrop Pattern of Cassava Adira I and Soybean Orba on Legume Retention and the Yield of Soybean Orba. The Research Institute, Faculty of Agriculture, Brawijaya University. Malang. p. 139. 
The Effect of Planting Time and Density of Corn (Zea Mays L.) On The Growth and Yield of ....

[7]. Nulhakim,L and M. Hatta. 2008. The Effect of Peanuts Variety and Planting Time of Sweet Corn on Growth and Yield in Intercropping System. Journal of Floratek. 2 (3) : 19 - 25

[8]. Onwueme, I.C. 1978. The Tropical Tuber Crop. John Wiley and Sons. Chichester.New York. Brisbane, Toronto. p. $199-224$ Paulus, J.M. 2005. Land Productivity, Competition, and Tolerance of Three Klo Sweet Potato in Intercropping System with Corn. Department of Agricultural Breeding, Faculty of Agriculture UNSTRAT Manado

[9]. Ridwan and Dahono.1995. Spacing and Planting Time of Corn in Intercrop with Peanuts on the Dry Land. A Research Institute of Foods, Sukarami.

[10]. Sitompul, S.M. and B. Guritno. 1995. Analysis on the Plant Growth. FP.UB. Gajah Mada Press. pp. 38 - 45.

[11]. Syaifuddin, I. Mado, Idris. 2010. Different Planting Time of Mungbean in Growing the corn. Journal of Agrosystem 6 (1) : $1-6$ Suminarti, N.E. 2009. Nutrient Compositions of Diverse Tubers from the Root Crops and Ground Rice. Unpublished.

[12]. Suwarto, S. Yahya, Handoko, M.A Chozin. 2005. Competition of Cassavas in Intercrop System. Bulletin of Agronomy 33 (2): 1-7

[13]. Syaifuddin. 2008. A Review on Potential Land to Grow Corn in Gowa and Takalar Regencies. Dissertation of Postgraduate Program University of Hasanuddin, Makasar.

[14]. Dosen Pembimbing Utama,

[15]. Dr. Ir. Nur Edy Suminarti, MS. NIP. 19580521198601200 